\title{
Recenzja
}

\section{Mariusz Popławski, Samorząd terytorialny w Królestwie Szwecji, Wydawnictwo Naukowe GRADO, Toruń 2007, ss. 126}

Książka autorstwa Mariusza Popławskiego przedstawia szwedzki model samorządu terytorialnego, wskazując zarówno na korzenie demokracji, jak i realizację nowoczesnej polityki lokalnej. Autor z jednej strony zwraca uwagę na poziom zaawansowania kultury politycznej i wyjątkowość społeczeństwa szwedzkiego czującego głębokie więzi społeczne, z drugiej zaś na fundament każdego mocnego państwa, czyli zapisy konstytucji. Ponadto podkreśla znaczenie tożsamości narodowej, wynikającej m.in. z „poszanowania wartości reprezentowanych przez Kościół Szwedzki oraz osoby monarchy jako historycznego symbolu szwedzkiej państwowości”, stwierdzając, że „społeczeństwo, które zna i akceptuje swoją tożsamość, może odważnie kreować swoje dalsze dzieje".

Praca Popławskiego poza wstępem i zakończeniem składa się z pięciu rozdziałów zatytułowanych kolejno: Szwecja - rys historyczny, społeczeństwo, ustrój i władza publiczna; Organizacja samorzadu terytorialnego; Finanse jednostek samorzadu terytorialnego w Szwecji - podstawy prawne oraz system wyrównawczy; Zadania samorzadów terytorialnych; Unia Europejska - doświadczenia szwedzkich samorządów terytorialnych.

Rozdział pierwszy zawiera charakterystykę współczesnego państwa szwedzkiego, uwzględniając położenie, powierzchnię, liczbę obywateli i strukturę zaludnienia. Następnie Autor sprawnie przechodzi do opisu zarysu historii Szwecji, zwracając szczególnie uwagę na: korzenie demokracji, charakterystykę społeczeństwa, prawa fundamentalne, tradycje szwedzkiego parlamentaryzmu, sprawny system sądowy, rolę monarchy i Kościoła Szwedzkiego, a także drogę, jaką przyszło pokonać Szwecji do integracji europejskiej. W podsumowaniu tego rozdziału autor podkreśla, że „dzięki wypracowaniu politycznej moralności, której wartości nadrzędne charakteryzuje szlachetność i dbałość o godność sprawowanego urzędu, uzyskuje się niespotykanie wysoki poziom zadowolenia obywateli”. Powszechnie Szwe- 
cję charakteryzuje się jako państwo opiekuńcze, bogate, które wypracowało wysokie standardy, szczególnie jeśli chodzi o środowisko naturalne. Jest to kraj w pełni demokratyczny z wrodzoną wręcz skłonnością Szwedów do solidarności międzyludzkiej i względnej tolerancji.

Drugi rozdział opisuje podstawowe założenia ustawy o samorządzie lokalnym z uwzględnieniem zasad ustrojowych, wyborów, liczby radnych czy audytem, rozumianym w Szwecji szerzej niż w innych państwach (nie tylko sprawy finansowe, ale kontrola dotycząca sfer politycznych i kierowniczych). Organy audytu nie badają jednak rady, gdyż jej członkowie posiadają mandat pochodzący od społeczeństwa. Autor podkreśla, że pomimo jasnych i przejrzystych reguł system szwedzki nie może być wprost przeniesiony na grunt innego państwa, gdyż jest on dostosowany do szwedzkiej rzeczywistości, i tu sprawdza się jako dobry, a sprawność prac radnych budzi podziw.

Kolejny rozdział pracy poświęcony jest szwedzkiemu systemowi finansów samorządowych, którego wyróżnikiem jest tzw. system wyrównawczy, który stanowi, że „wszystkie gminy i wszystkie województwa mają mieć możliwość świadczenia usług na podobnym poziomie”. Dość szczegółowo jest opisany Samorządowy system wyrównywania finansowego wprowadzony dnia 1 stycznia 2005 r., który można podzielić na „pięć osobnych podsystemów: wyrównanie dochodów, wyrównanie kosztów, granty strukturalne, granty transformacyjne, opłata/grant korekcyjny". System stanowi swoistą konsekwencję lansowanej od lat polityki welfare state.

Rozdział czwarty traktuje o obowiązkowych i nieobowiązkowych zadaniach samorządu terytorialnego w państwie szwedzkim, którego polityka określana jest jako „polityka trzeciej drogi, wytyczonej pomiędzy kapitalizmem a socjalizmem". Autor poświęca sporo uwagi: świadczeniom społecznym, narodowemu systemowi szkolnictwa na poziomie gminy i województwa, jednostkom nauczania, mieszkalnictwu, planowaniu i budownictwu w gminie, opiece zdrowotnej i medycznej, zbiórce i zarządzaniu odpadami, ochronie cywilnej i służbom ratowniczym oraz służbom technicznym i infrastrukturze.

Ostatni rozdział to rozważania na temat doświadczeń Szwecji w zderzeniu z unijną rzeczywistością. Zwrócono uwagę na proces regionalizacji w Europie, podkreślając, że „regionalizm w Szwecji charakteryzuje się dobrowolnością zrzeszania się w celu realizacji danego założenia, a województwa stały się podmiotem, w którym skupiona jest polityka regionalna”. Wskazano na 
współpracę międzynarodową gmin szwedzkich na poziomie miast partnerskich i bliźniaczych jeszcze przed akcesją z UE, co nie tylko pomogło na wymianę doświadczeń, ale również na stworzenie więzi gospodarczych. Autor pokusił się o stwierdzenie, że „członkostwo wpływa pozytywnie na demokrację na szczeblu lokalnym”, a „z integracji korzystają najlepiej przygotowani”. Szwecja niewątpliwie może być tego dobrym przykładem.

Praca Mariusza Popławskiego wpisuje się w istotny i aktualny temat rozważań nad społeczeństwem obywatelskim. Pokazanie zasad funkcjonowania samorządu terytorialnego w Królestwie Szwecji przy jednoczesnych uwzględnieniem specyfiki społeczności lokalnych i historii podnosi walor poznawczy tej pracy. W przypisach znajdujemy liczne źródła anglojęzyczne, a analiza tematu została oparta w dużej mierze na aktach prawnych i dokumentach. Szkoda, że w pracy jasno nie została określona cezura czasowa, co ułatwiło by dookreślenie formy „dziś” wielokrotnie użytej w publikacji. Również wydawca nie określił roku wydania książki, co stanowi formalne niedopatrzenie.

Reasumując, należy stwierdzić, że jest to wartościowa pozycja, wzbogacająca polską literaturę naukową z zakresu polityki lokalnej państw skandynawskich. Stanowi istotną wartość poznawczą dotyczącą samorządu terytorialnego w Królestwie Szwecji. Praca napisana jest poprawnym językiem, przejrzyście, uzupełniona tabelami. Książka jest godna polecenia tym wszystkim, którzy interesują się funkcjonowaniem samorządu lokalnego.

Katarzyna Forst (Uniwersytet Śląski) 